Note

\title{
Characterization of a new potyvirus causing mosaic and flower variegation in Catbarantbus roseus in Brazil
}

\author{
Sheila Conceição Maciel ${ }^{1}$, Ricardo Ferreira da Silva ${ }^{1}$, Marcelo Silva Reis ${ }^{2}$, Adriana Salomão Jadão ${ }^{3}$, \\ Daniel Dias Rosa ${ }^{1}$, José Segundo Giampan ${ }^{4}$, Elliot Watanabe Kitajima ${ }^{3}$, Jorge Alberto Marques \\ Rezende $^{3 *}$, Luis Eduardo Aranha Camargo ${ }^{3}$ \\ ${ }^{1}$ USP/ESALQ - Programa de Pós-Graduação em Fitopatologia. \\ ${ }^{2}$ Centro de Citricultura Sylvio Moreira/Bioinformática - 13490-970 - Cordeirópolis, SP - Brasil. \\ ${ }^{3}$ USP/ESALQ - Depto. de Fitopatologia e Nematologia - C.P. 09 - 13418-900 - Piracicaba, SP - Brasil. \\ ${ }^{4}$ LAPAR - Area de Proteção de Plantas - C.P. 481 - 86047-902 - Londrina, PR - Brasil. \\ *Corresponding author 〈jamrezen@esalq.usp.br> \\ Edited by: Luís Reynaldo Ferracciú Alleoni
}

\begin{abstract}
Catharanthus roseus is a perennial, evergreen herb in the family Apocynaceae, which is used as ornamental and for popular medicine to treat a wide assortment of human diseases. This paper describes a new potyvirus found causing mosaic symptom, foliar malformation and flower variegation in C. roseus. Of 28 test-plants inoculated mechanically with this potyvirus, only C. roseus and Nicotiana benthamiana developed systemic mosaic, whereas Chenopodium amaranticolor and C. quinoa exhibited chlorotic local lesions. The virus was transmitted by Aphis gossypii and Myzus nicotianae. When the nucleotide sequence of the CP gene (768nt) was compared with other members of the Potyviridae family, the highest identities varied from 67 to $76 \%$. For the $3^{\prime}$ UTR (286nt), identities varied from 16.8 to $28.6 \%$. The name Catharanthus mosaic virus (CatMV) is proposed for this new potyvirus.

Keywords: RT-PCR, Apocynaceae, periwinkle, diagnose, genome sequencing
\end{abstract}

\section{Introduction}

Catharanthus roseus is known as the common periwinkle or Madagascar periwinkle. It is a perennial, evergreen herb in the family Apocynaceae, which grows up to $80 \mathrm{~cm}$ high; has glossy, dark green leaves and bloom during summer. The flowers range from white to hot pink to purple (Heywood, 1993). The plant has historically been used in popular medicine to treat a wide assortment of human diseases, such as diabetes, high blood pressure, as it contains more than 150 useful alkaloids. Periwinkles also contain alkaloids acting as powerful tranquilizers (Favali et al., 2004).

The occurrence of plants of $C$. roseus exhibiting mosaic symptoms and leaf malformation associated to virus infection is very common in Brazil. Espinha and Gaspar (1997), for instance reported a mosaic disease of $C$. roseus caused by Cucumber mosaic virus (CMV), whereas Seabra et al. (1999) described the occurrence of an uncharacterized potyvirus causing mosaic and leaf malformation in this species in São Paulo State (SP), Brazil. Plants of $C$. roseus exhibiting mosaic symptoms followed by leaf malformation and flower variegation were collected from a garden in Piracicaba, SP (Figure 1). This paper reports on biological, immunological and molecular data, which indicate that the disease is caused by a new potyvirus, hereby named Catharanthus mosaic virus (CatMV).

\section{Materials and Methods}

Diseased $C$. roseus was established by vegetative propagation under greenhouse conditions. After local lesion transfer through Chenopodium quinoa, a virus isolate was established in C. roseus. Infectious sap prepared with $0.02 \mathrm{M}$ phosphate buffer, $\mathrm{pH} 7.0$, containing $0.02 \mathrm{M}$ sodium sulfite was mechanically inoculated onto carborundum-dusted leaves of Capsicum annum, Carica papaya, C. roseus, Chenopodium amaranticolor, C. quinoa, Crotalaria juncea,
Cucumis sativus, Cucurbita pepo cv. Caserta, C. moschata cv. Menina Brasileira, Datura stramonium, Glycine max, Gomphrena globosa, Solanum bycopersicum, Nicotiana benthamiana, $N$. clevelandii, $N$. glutinosa, $N$. tabacum cvs. Havana, Turkish and TNN, Passiflora edulis f. flavicarpa, Phaseolus vulgaris cvs. BT-2 and Carioca, and Vigna unguiculata cvs. Branco, Gurgueia, Olho marrom, Monteiro, Mulato and Pitiuba. These test-plants belong to the families Apocynaceae, Amaranthaceae, Caricaceae, Chenopodiaceae, Curcubitaceae, Leguminosa, Passifloraceae and Solanaceae. Evaluations were based on the development of local and/ or systemic symptoms as well as by serological assays using antiserum produced against CatMV. Partial host range assay was repeated once using two test-plants each time.

Leaf fragments from naturally infected periwinkle and experimentally infected test-plants were processed for ultra structural histology as described by Kitajima and Nome (1999) and examined in a Zeiss EM 900 transmission electron microscope.

Aphis gossypii, Myzus nicotianae and Toxoptera citricidus reared on healthy $C$. roseus, $N$. tabacum and Citrus spp., respectively, were used for aphid transmission tests. Aphids were removed from the colony with a fine tip brush, and after fasting for $30 \mathrm{~min}$ were transferred to CatMV-infected $C$. roseus for a 10 min virus acquisition period. They were then transferred to healthy plants of $C$. roseus in number of 1,3 and 6 aphids per plant. Five plants were exposed to each combination of species and number of aphids and about $24 \mathrm{~h}$ later were sprayed with insecticide to kill the insects. Evaluations were based as described above.

The potyvirus was purified from infecting C. roseus according to Marinho and Kitajima (1989). Purified viral preparations emulsified with incomplete Freund's adjuvant (1:1) were injected intramuscularly in the thigh of a four months-old New Zealand rabbit for antiserum production. Four injections were made at weekly intervals, with $1 \mathrm{~mL}$ of emulsion containing $100 \mu \mathrm{g}$ of purified virus. The clean serum was stored at $-20^{\circ} \mathrm{C}$. The anti- 

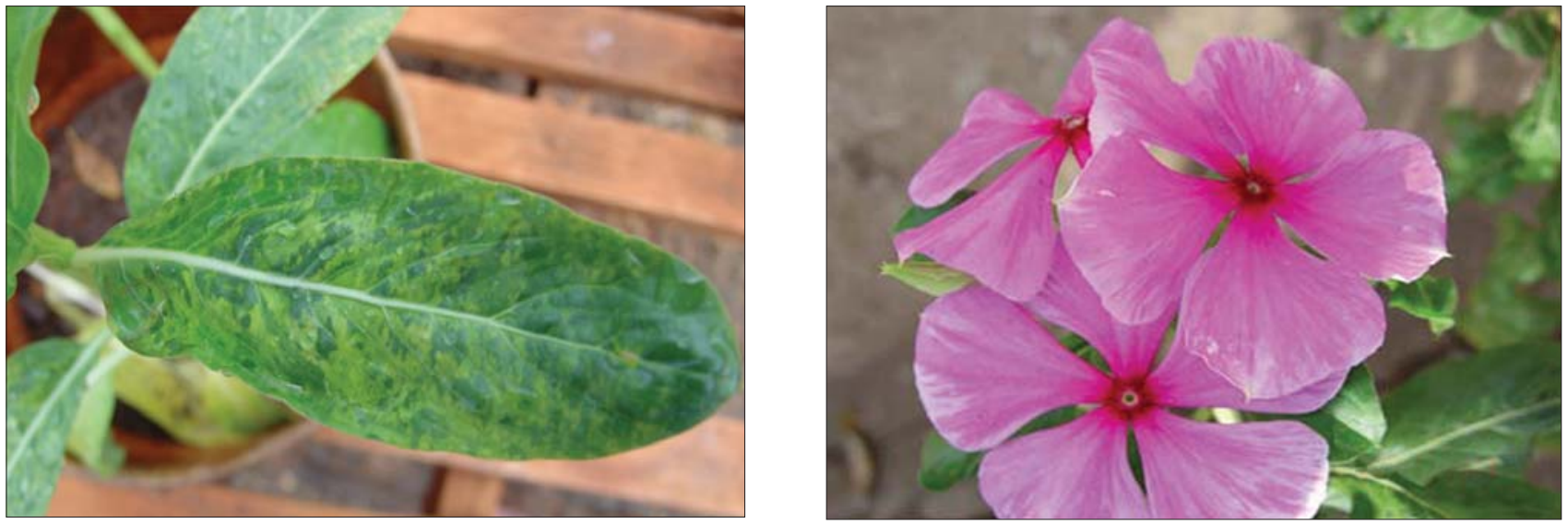

Figure 1 - Symptoms of mosaic on leaf (left) and flower variegation (right) on Catharanthus roseus.

serum was evaluated against the homologous virus by modified PTA-ELISA (plate trapped antigen-enzyme linked immunosorbent assay) (Mowat and Dawson, 1987). Extracts from healthy C. roseus was used as control. A reaction was considered positive when the absorbance value was three times higher than the average absorbance value of the reactions with healthy extract.

Molecular weight of the coat protein (CP) of CatMV was estimated by SDS-polyacrylamide gel electrophoresis, after denaturizing the $\mathrm{CP}$ of purified viral suspension, using a molecular weight marker in the range of 6.0 to $181.8 \mathrm{kDa}$ (BeachMark Pre-Stained Protein Ladder, Invitrogen) (Conci, 1999). Electrophoresis was performed with a BioRad MiniProtean II apparatus. Protein was transferred to nitrocellulose membrane and the identity of the CP was revealed by Western blot reaction with polyclonal antiserum $(1: 1,000)$ rose against CatMV. The nitrocellulose membrane was blocked with $1 \%$ bovine serum albumin (BSA) diluted in PBS. Alkaline phosphatase conjugated IgG (Sigma A-8025) was diluted 1:32,000. Finally, 5-brome-4-chlorine-3-indolyl phosphate/nitroblue tetrazolium pH 9.5 (NBT/BCIP) substrate was added. Reaction was stopped by washing the membrane with distilled water.

The total RNA was extracted from plants infected with the potyvirus with Trizol, and then used for synthesis of three overlapping cDNA fragments by RT-PCR using M-MLV reverse transcriptase and Taq DNA Polymerase (Invitrogen Corporation), according to manufacturer's recommendations. A set of primers was used for RT-PCR of the $3^{\prime}$ terminal of the virus RNA: potyviruses universal primers PV1 (5'- $\left.T_{17}(A / G / C)-3^{\prime}\right)$ and PV2 (5'- GGB AAY AGY GGD CAR CC - 3') (Gibbs and Mackenzie, 1997), and two internal primers which anneal to the region of the amino acid conserved motif WCIEN of the CP gene of potyviruses: primer WCIEN-sense (5'ATGGTT'TGGTGYATYGARAAT-3'), and WCIEN-antisense (5'-ATTRTCYATYCACCAAACCAT-3') (Mota et al., 2004). An additional antisense primer, designed based on the partial sequence of the CP gene of the studied virus (CatMV-CP 5'CCTCACTCATCTGGAACTTC-3'), was also used. The first strand cDNA was synthesized from viral RNA with anti-sense PV1 primer, which anneals to the 3' terminal of potyviruses, essentially as described by Gibbs and Mackenzie (1997).

The first PCR was carried out with anti-sense PV1 primer and WCIEN-sense primer, whereas the second PCR was carried out with the WCIEN-antisense primer and the sense PV2 primer, which an- neals to the 3' terminal of the type b nuclear inclusion (Nib) gene of potyviruses. A third PCR reaction was carried out with CatMV-CP and PV2 primers. The thermocycler (MJ Research PTC 200) amplification profile when using primers PV1/WCIEN-sense and WCIENantisense/PV2 was set to $94^{\circ} \mathrm{C}$ for $2 \mathrm{~min}$, followed by 35 cycles of $94^{\circ} \mathrm{C}$ for $30 \mathrm{~s}, 56^{\circ} \mathrm{C}$ for $45 \mathrm{~s}$ and $72^{\circ} \mathrm{C}$ for $1 \mathrm{~min}$, followed by a final elongation step at $72^{\circ} \mathrm{C}$ for $10 \mathrm{~min}$. For primers CatMV-CP/PV2 the annealing temperature was increased to $58^{\circ} \mathrm{C}$ and the extension time was changed to $80 \mathrm{~s}$. Amplified cDNA fragments were visualized in $1 \%$ agarose gel stained with Syber safe, under UV light. A 1 $\mathrm{kb}$ DNA ladder was used as a molecular weight standard.

PCR fragments were directly sequenced in an ABI Prism 377 DNA Sequencer, according to the ABI Prism BigDye terminator cycle sequencing kit (Applied Biosystems). Nucleotide sequences were assembled using the phred/phrap/consed program (Ewing et al., 1998) and the final consensus sequence was compared with sequences of other potyviruses deposited in GenBank using the BlastN and BlastX algorithms (Altschul et al., 1997). Deduced amino acid sequences were obtained and aligned with ClustalX 1.83 (Thompson et al., 1997). A cluster analysis of the deduced amino acid sequence of the complete coat protein coding region was performed with the minimum-evolution method, with 10,000 bootstrap replicates (implemented in MEGA 3) (Tamura et al., 2007).

\section{Results and Discussion}

Mechanical transmission assays showed that CatMV has a limited host range. Of the 28 test-plants mechanically inoculated, only $C$. roseus and $N$. benthamiana showed systemic mosaic and reduction of the leaf blade. C. amaranticolor and C. quinoa exhibited chlorotic local lesions only in the inoculated leaves. Only leaf extracts from symptomatic test-plants reacted with antiserum against CatMV in PTA-ELISA.

Ultra thin sections prepared from leaf of symptomatic $C$. roseus and $N$. benthamiana plants examined under transmission electron microscope revealed the presence of flexuous filamentous particles, ca. $10 \mathrm{~nm}$ wide and various lengths. Cylindrical inclusions, characteristic of potyvirus infections and of type II in the Edwardson's classification (Edwardson, 1974), were observed in the cytoplasm of some epidermal, parenchyma and vascular cells (Figure 2a, b).

A. gossypii and $M$. nicotianae were able to transmit CatMV. Transmission efficiencies of $A$. gossypii were $20 \%, 40 \%$ and 
$60 \%$ when 1, 3 and 6 viruliferous aphids were transferred to healthy test-plants, respectively. Transmission efficiency of $M$. nicotianae was $20 \%, 20 \%$ and $60 \%$ when 1,3 and 6 viruliferous aphids were transferred to healthy test-plants, respectively. T. citricidus did not transmit the potyvirus. Infection of symptomatic $C$. roseus was confirmed by PTA-ELISA. A. gossypii is an aphid species frequently found colonizing $C$. roseus.

Purification process yield concentrated suspension of flexuous particles of high purity (data not shown), which when injected in the rabbit produced a specific antiserum. Results of PTA-ELISA showed that the antiserum anti-CatMV reacted positively with the homologous virus $\left(\mathrm{A}_{405}\right.$ infected $=0.322$; healthy $\left.=0.058\right)$. CatMV CP labeled with polyclonal antiserum against CatMV showed a molecular mass about $34 \mathrm{kDa}$ according to the Western blot assay.

Three cDNA fragments of approximately 800,1000 and 1400 bp each were amplified using the primers PV1/WCIEN-sense,
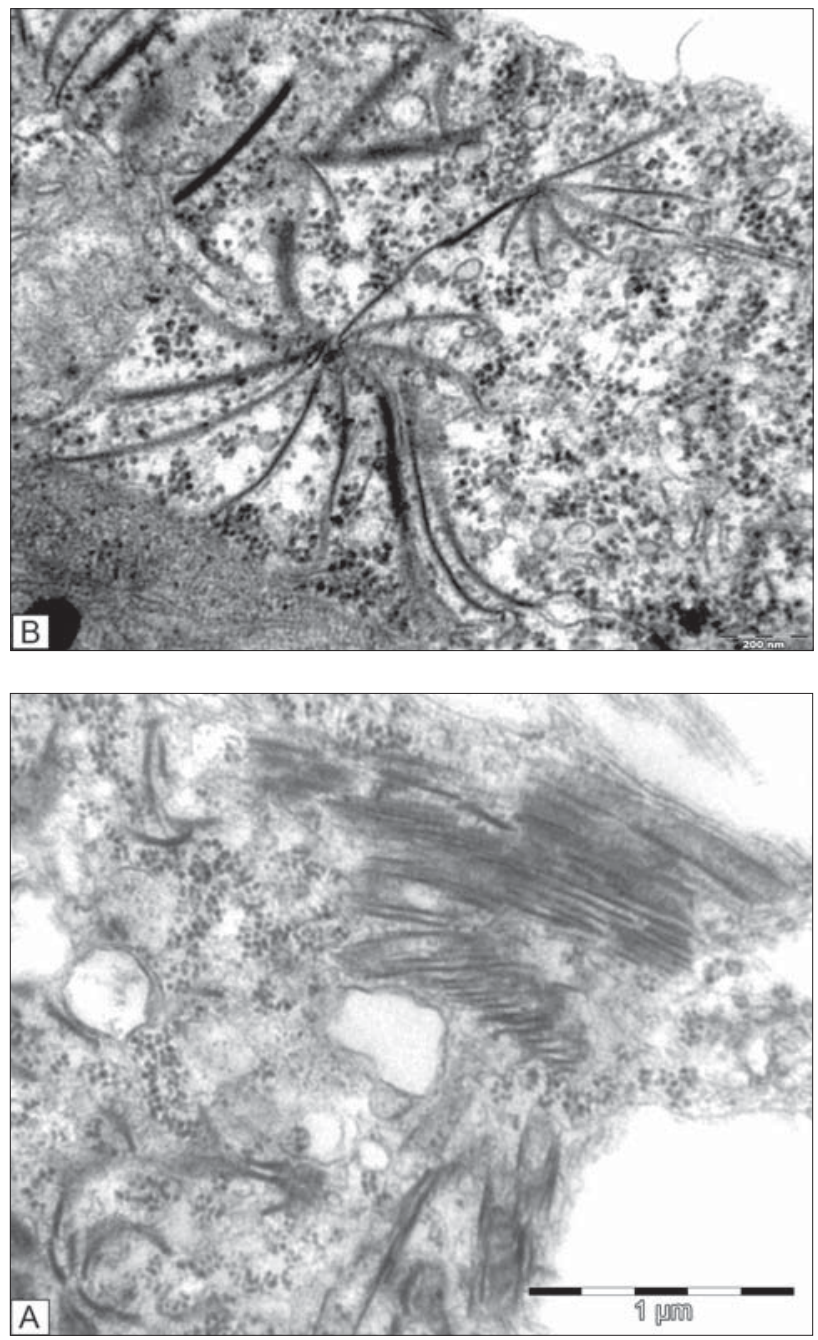

Figure 2 - Transmission electron micrographs of thin sections from leaf cells infected by Catharantus mosaic virus (CatMV). A. Cylindrical inclusions and thin, flexuous particles can be seen in the cytoplasm of mesophyl parenchyma cell from naturally infected Catharanthus roseus. B. The same from mechanically infected Nicotiana benthamiana.
CatMV-CP/PV2 and PV2/WCIEN-antisense. The three fragments were sequenced in the forward and reverse directions. The partial sequence from the viral RNA had 1,654 nt, comprising part of the type b nuclear inclusion $(\mathrm{Nib})$ gene $(600 \mathrm{nt})$, the entire $\mathrm{CP}$ gene (768 nt), and the 3' untranslated region (3' UTR) (286 nt), not including the polyA tail. The Nib and $\mathrm{CP}$ genes encode a polypeptide with 455 amino acid residues, of which 256 correspond to the CP. The cleavage site for Nib/CP was identified as Q/S. The DAG motif, which is related with aphid transmission, is also present in the CP. Other conserved motifs found in the CP were MVWCIENGTSP, AFDF, and QMKAAAL. Nucleotide sequence was deposited in GenBank with accession number DQ365928.

When the nucleotide and deduced amino acid sequences of the CP gene were aligned with corresponding sequences of other members of the Potyviridae family, the highest identities were with the putative species Omphalodes virus Y (76 \%) and East Asian Passiflora virus (71\%), respectively. The 3' UTR sequence had the highest identity $(28.6 \%)$ with that of Pepper yellow mosaic virus (Table 1). The dendrogram obtained from the alignment of the deduced amino acid sequences of the $\mathrm{CP}$ of different potyvirus is shown in Figure 3. It has been proposed the threshold of 80 $\%$ as the minimum deduced amino acid sequence identity of the $\mathrm{CP}$ gene needed to define a new potyvirus species (Fauquet et al., 2005). In addition, Adams et al. (2005) suggested $76-77 \%$ nucle-

Table 1 - Comparison of percentage of identities of nucleotide (nt) and amino acid (aa) sequences between Catharanthus mosaic virus (CatMV) and species of the genus Potyvirus.

\begin{tabular}{|c|c|c|c|c|}
\hline \multirow[t]{2}{*}{ Virus } & \multirow[t]{2}{*}{$\begin{array}{c}\text { GenBank } \\
\text { Access }\end{array}$} & \multicolumn{2}{|c|}{ Coat protein } & \multirow{2}{*}{$\begin{array}{c}3^{\prime} \\
\text { UTR } \\
\mathrm{nt}\end{array}$} \\
\hline & & nt & aa & \\
\hline Carrot thin leaf virus & AF203530 & 72 & 67 & 18.1 \\
\hline Colombian datura virus & AM113754 & 69 & 65 & 26.4 \\
\hline East Asian Passiflora virus & AB185021 & 71 & 71 & * \\
\hline Hyacinth mosaic virus & EF203681 & 70 & 64 & $*$ \\
\hline Johnsongrass mosaic virus & AY387811 & 71 & 67 & * \\
\hline Omphalodes virus $\mathrm{Y}$ & AY974328 & 76 & 62 & 21.1 \\
\hline Onion yellow dwarf virus & DQ519034 & 73 & 65 & 21.6 \\
\hline Ornithogalum virus 2 & AY994103 & 73 & 64 & * \\
\hline Pea seed-borne mosaic virus & NC_001671 & 61 & 60 & 33.0 \\
\hline Pepper severe mosaic virus & X66027 & 70 & 64 & 16.8 \\
\hline Pepper veinal mottle virus & NC_011918 & 52 & 61 & 8.0 \\
\hline Pepper yellow mosaic virus & AF348610 & 67 & 65 & 28.6 \\
\hline Potato virus $Y$ & EF026076 & 69 & 63 & 21.5 \\
\hline $\begin{array}{l}\text { Ranunculus mild mosaic } \\
\text { virus }\end{array}$ & EF445546 & 70 & 63 & 20.5 \\
\hline Sugarcane mosaic virus & X05040 & 71 & 67 & $*$ \\
\hline $\begin{array}{l}\text { Sunflower chlorotic spot } \\
\text { virus }\end{array}$ & AF538686 & 70 & 66 & $*$ \\
\hline $\begin{array}{l}\text { Watermelon leaf mottle } \\
\text { virus }\end{array}$ & AF028004 & 72 & 63 & 25.8 \\
\hline Watermelon mosaic virus & NC_006262 & 60 & 62 & 6.0 \\
\hline
\end{tabular}

Sci. Agric. (Piracicaba, Braz.), v.68, n.6, p.687-690, November/December 2011 


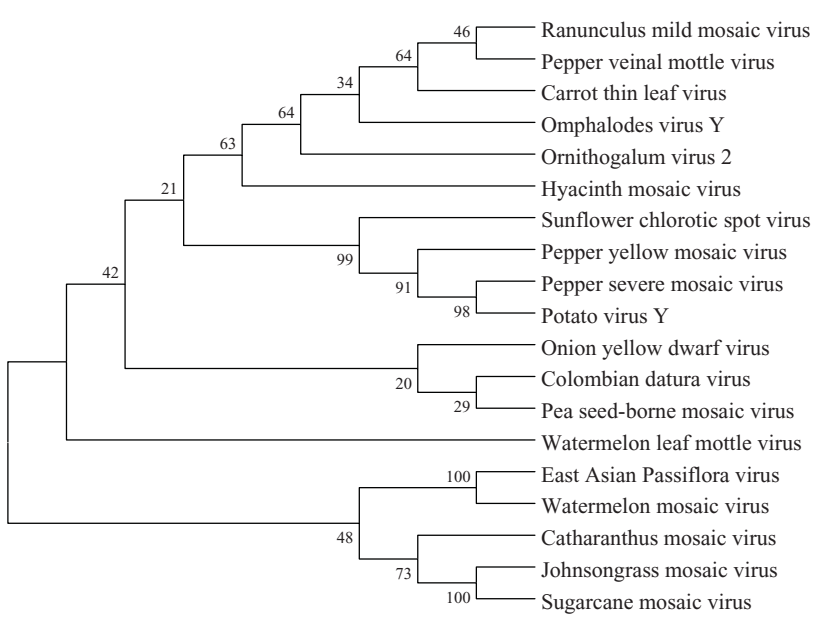

Figure 3 - Dendrogram constructed based on alignments of the deduced amino acid sequence of the complete coat protein coding region of Catharanthus mosaic virus and selected potyviruses. Tree was generated with the MEGA 4.0 software using the minimum-evolution method, with 1,000 bootstrap replicates. Numbers close to ramification indicate the percentage of bootstrap analyses supporting the grouping of each branch. GenBrank accession numbers for all potyvirus species are listed in Table 1.

otide sequence identity of the CP gene as the optimal value for species delineation. According to these criteria, CatMV should be considered a member of a distinct species in the genus Potyvirus. Given the threshold of $80 \%$ as the minimum deduced amino acid sequence identity of the CP gene needed to define a new potyvirus species, (Fauquet et al., 2005), then CatMV must be considered a distinct species from those previously described for the genus Potyvirus. Our conclusion is further strengthened by the fact that the identity of the 3' UTR sequence, which was also previously used as a species-defining criterion in the genus Potyvirus (van Regenmortel et al., 2002), was also below the level of identity $(75 \%)$. Other potyviruses reported as able to infect C. roseus are: Pea seed-borne mosaic virus; Pepper veinal mottle virus, and Watermelon mosaic virus (Brunt et al., 1996).

Although C. roseus is mainly used as an ornamental, the mosaic and leaf malformation symptoms caused by this potyvirus clearly affects plant development leading to losses if parts of the plants are used for the extraction of phytotherapics. In addition, we were able to collect only 50 seeds from infected plants, which is a very small number for this otherwise prolific plant species. Furthermore, only 29 of these seeds germinated giving rise to healthy plants based on symptom expression and serological assay, suggesting that CatMV affects their production and viability. Thus, since $C$. roseus can be propagated by seeds and vegetative clones, the former procedure might be preferable as a control measure of CatMV, in spite of the very small number of seeds tested to evaluate transmissibility of this virus. However, if clonal propagation is used, the propagative material should be taken from healthy plants. Finally, considering that CatMV has an apparently narrow host range and did not infect plants of some economically important crops, we conclude that the impact of this viral disease may be restricted to $C$. roseus.

\section{References}

Adams, M.J.; Antoniw, J.F.; Fauquet, C.M. 2005. Molecular criteria for genus and species discrimination within the family Potyviridae. Archives of Virology 150: 459-479.

Altschul, S.F.; Madden, T.L.; Schaffer, A.A.; Zhang, J.; Zhang, Z.; Miller, W.; Lipman, D.J. 1997. Gapped BLAST and PSI-BLAST: a new generation of protein database search programs. Nucleic Acids Research 25: 3389-3402.

Brunt, A.A.; Crabtree, K.; Dallwitz, M.J.; Gibbs, A.J.; Watson, L.; Surcher, E.J., eds. 1996. Plant Viruses Online: Descriptions and lists from the VIDE database.

Conci, V.L. 1999. Serological Techniques. p. 23-39. In: Do Campo, D.; Lenardon, S., eds. Methods for detection of systemic pathogens. IFFYVE/INTA, Córdoba, AR. (in Spanish).

Edwardson, J.R. 1974. Some properties of the potato virus Y-group. Institute of Food and Agricultural Science/University of Florida, Gainesville, FL, USA. 398 p. (Florida Agricultural Experiment Station Monography, Series 4).

Espinha, L.M.; Gaspar, J.O. 1997. Partial characterization of cucumber mosaic virus isolated from Catharanthus roseus. Fitopatologia Brasileira 22: 209-212. (in Portuguese, with abstract in English).

Ewing, B.; Hillier, L.; Wendl, M.; Green, P. 1998. Base calling of automated sequencer traces using phred. I. Accuracy assessment. Genome Research 8: $175-185$.

Fauquet, C.M.; Mayo, M.A.; Maniloff, J.; Desselberger, V.; Ball, L.A. 2005. Virus Taxonomy: Classification and Nomenclature of Viruses; Eighth Report of the International Committee on Taxonomy of Viruses. Elsevier Academic Press, San Diego, CA, USA.

Favali, M.A.; Musetti, R.; Benvenuti, S.; Bianchi, A.; Pressacco, L. 2004. Catharanthus roseus L. plants and explants infected with phytoplasmas: alkaloid production and structural observations. Protoplasma 223: 45-51.

Gibbs, A.; Mackenzie, A. 1997. A primer pair for amplifying part of the genome of all potyvirids by RT-PCR. Journal of Virological Methods 63: 9-16.

Heywood, V.H. 1993. Flowering Plants of the World. Oxford University Press, New York, NY, USA.

Kitajima, E.W.; Nome, C.F. 1999. Electron microscopy in plant virology. p. 59-87. In: Do Campo, D.; Lenardon, S., eds. Methods for detection of systemic pathogens. IFFYVE/INTA, Córdoba, AR. (in Spanish).

Marinho, V.L.A.; Kitajima, E.W. 1989. A simplified method to purify some potiviruses. Fitopatologia Brasileira 14: 91-93. (in Portuguese, with abstract in English).

Mowat, W.P.; Dawson, S. 1987. Detection of plant viruses by ELISA using crude sap extracts unfractionaded antisera. Journal of Virological Methods 15: 233-247.

Mota, L.D.C.; Della Vecchia, M.G.S.; Gioria, R.; Kitajima, E.W.; Rezende, J.A.M.; Camargo, L.E.A.; Amorim, L. 2004. Pfaffia mosaic virus: a new potyvirus found infecting Pfaffia glomerata in Brazil. Plant Pathology 53: 368-373.

Seabra, P.V.; Alexandre, M.A.V.; Rivas, E.B.; Duarte, L.M.L. 1999. Occurrence of a Potyvirus in Catharanthus roseus. Arquivos do Instituto Biológico 66: 116. (in Portuguese).

Tamura, K.; Dudley, J.; Nei, M.; Kumar, S. 2007. MEGA4: molecular evolution genetics analysis (MEGA) software version 4.0. Molecular Biology Evolution 24:1596-1599.

Thompson, J.D.; Gibson, T.J.; Plewniak, F.; Jeanmougin, F.; Higgins, D.G. 1997. The ClustalX windows interface: flexible strategies for multiple sequence alignment aided by quality analysis tools. Nucleic Acids Research 24: 4876-4882.

Van Regenmortel, M.H.V.; Fauquet, C.M.; Bishop, D.H.C.; Cartens, E.B.; Estes, M.K.; Lemon, S.M.; Maniloff, J.; Mayo, M.A.; McGeoch, D.J.; Pringle, C.R.; Wickner, R.B. 2002. Virus Taxonomy: Classification and Nomenclature of Virus; Seventh Report of the International Committee on Taxonomy of Viruses. Academic Press, San Diego, CA, USA.

Received June 21, 2010

Accepted March 14, 2011 